\title{
A Sociological Analysis of Economic Impediments of Development in Education Sector: A Case of Southern Punjab (Pakistan)
}

\author{
Tehmina Sattar \\ Department of Sociology \\ Bahauddin Zakariya University, Multan (Pakistan) \\ E-mail address tehminasattar@hotmail.com
}

Received: January 28, 2012 Accepted: February 15, 2012 DOI: 10.5296/ijafr.v2i1.1456

\begin{abstract}
The rate of schooling success in adult population at primary, secondary and higher education has positive relationship with the growth of GNP. The acquisition and application of knowledge by different countries has been governed largely by whether their population has acquired traits and motivations associated with formal schooling. They are dependent heavily on the larger part of economic conditions and ideological influences. Government is encouraging private sector investment in education sector but it more focuses on the urban areas not only denying equitable admittance to basic education for people of backward areas but also perpetuating poor educational status of the people. There are various economic impediments that are hampering the process of development in education sector of Pakistan. These impediments comprise of disparities between region and gender, lack of trained teachers, deficiency of proper teaching materials, poor physical infrastructure of schools and low levels of public investment in primary education sector. A sample size of $N 1=600$ respondents $(n 1=200$ parents, $n 2=200$ students and $n 3=200$ teachers $)$ was taken from $n 4=50$ affiliated schools (from BISE) through multistage sampling technique. Data was collected through interview schedule and then statistical test of ANOVA was used for the purpose of establishing the causal relationship among the dependent and independent variables. Thus the researcher concluded that lack of well designed curriculum, underinvestment in education sector, corruption, inflation, low parental income and cost of schooling deprives the children from getting quality education. Thus increasing the allocation of funds to education sector, provision of administrative autonomy, lessening the direct cost of schooling and improvement in infrastructural facilities are the major remedies for reducing the negative impacts of these economic impediments on education sector of Southern Punjab (Pakistan).
\end{abstract}

Keywords: Impediments, development, budget allocation, infrastructure, poverty 


\section{Introduction}

South Asian countries have experienced rapid growth over the last three decades with lower levels of inequality. Reduced poverty and income inequality leads to more accentuate on the basic education, labor demand and economic growth. The rapid growth and reduced inequality escorted to higher demand and supply of education (Fasih, 2008). Moreover low levels of income inequality may directly stimulate economic growth. Accordingly there is a causal relationship between low inequality, economic growth and educational attainment. Thus educational policies show high investment on education sector. It is the key to sustainable development because it has the influence on productivity effects and reduced income inequality (Bridsall, et al. 1995). Since education is an investment, there is a significant positive correlation between education and economic productivity. When people are educated, their standards of living are likely to improve, since they are empowered to access productive ventures, which will ultimately leads to an improvement in their livelihoods (Nconco, 2006). The role of education therefore, is not just to impart knowledge and skills that enable the beneficiaries to function as economies and social change agents in society, but also to enhance the significant impacts on ideologies, rationales and aspirations which are the necessary prerequisites for the process of sustainable development (Anderson and Dexter, 2005). The straightforward linkage between education is through the improvement of labor skills, which in turn increases opportunities for well paid productive employment. Accordingly it will enable the citizens of any nation to fully exploit the potential positively (Aikman and Unterhalter, 2005).

Relative to the other countries which have almost same per capita income levels as Pakistan these countries are mostly investing on human capital. This investment on human capital is measured by educational performance of any country. Relative and absolute poverty are serious obstacles to human capital accumulation in Pakistan (Sawada, 1997). Expenditure allocations predict that input use should be chosen so that the marginal product per dollar of each input is equalized (Institute of Social and Policy Sciences, 2009). The existing literature shows that marginal product per dollar of inputs not directly valued by teachers are commonly 10-100 times higher than input valued by teachers. This illustrates that inputs which provide direct benefits to educators (like teachers wages) are used relative to inputs that contribute directly to education output (like books or instructional materials). This shows very high ratio of teachers to parents and teachers to students influence in the determination of expenditures. This entails that education reforms shifts the relative strengths of parents verses teachers in allocation of expenditures and can sometimes lead to massive gains in the cost effectiveness of the schools (Pritchett and Filmer, 1999). In spite of larger differences in social structures, cultural and historical backgrounds, higher education have to face serious challenges. Higher education entails good economic conditions but unfortunately poor countries have to face a lot of economic deprivation regarding higher education (Chaudhry, et al. 2009). The most significant economic issues in education sector are as follows:

1) Lack of resources: Financial adjustments required by a highly competitive and unpredictable global economy but regrettably the education sector of Pakistan lacks the basic resources that are required for the development of education sector in 
Pakistan.

2) Inadequate budget allocation to education sector: Government of Pakistan is allocating lowest budget to education sector from the onset of technological transformations. This economic constraint is the base of many economic impediments in education sector of Pakistan (like poor infrastructural development, lack of schools and lack of proper training materials etc).

3) Cost of schooling: Cost of schooling is the major economic impediment that is accountable for low enrollment rate in education sector of Pakistan. This direct cost of schooling includes school books, school uniforms and other educational expenditures etc.

4) Child labor: Limited family earning is the major determinant of Intrahousehold and Extrahousehold child labor. This economic impediment is the major deprivation factor for children (in getting low quality education or no education at all) (Jam, 2005).

The enrollment rate and education accomplishment is directly influenced by gender, poverty, family structure and investment in children education. They have momentous impact on investment in children education such as poverty, household structure and economic well being of the individuals (Ali, 1997). Improved economic status of the parents escorts towards more investment on their children education (both males and females but especially for the females) but this is not necessarily true because many times well being and economic status even lead towards gender biasness. In addition to this family structure (as measured by number of children in the household of diverse age groups and child relationship to the head of the household) are also found to have the significant influences on educational investment (Shapiro and Tambashe, 2001).

Government is not able to invest more on education sector. The population of Pakistan is growing at the faster pace but the investment in education sector is not in an passable amount (Bano, 2008). Government allocation of education budget is not ample to meet the needs of education sector. This budget lags behind the other South Asian countries. Due to this lag the development rate of Pakistan is far below the third world countries (Memon, 2007).

\begin{tabular}{|c|c|c|c|c|c|c|}
\hline \multicolumn{7}{|c|}{ Percentage share in educational expenditure by province and level of education } \\
\hline & Federal & Punjab & Sind & NWFP & Baluchistan & Pakistan \\
\hline \multicolumn{7}{|c|}{ 2000-2001 } \\
\hline $\begin{array}{l}\text { Primary } \\
\text { education }\end{array}$ & 15.58 & 56.97 & 48.39 & 47.69 & 41.82 & 47.79 \\
\hline $\begin{array}{l}\text { Secondary } \\
\text { education }\end{array}$ & 17.28 & 26.55 & 30.56 & 36.92 & 31.09 & 28.27 \\
\hline $\begin{array}{l}\text { College and } \\
\text { universities }\end{array}$ & 33.17 & 9.12 & 8.58 & 7.65 & 5.04 & 11.30 \\
\hline Professional & 25.34 & 4.11 & 5.59 & 5.10 & 9.20 & 7.41 \\
\hline
\end{tabular}




\begin{tabular}{|c|c|c|c|c|c|c|}
\hline \multicolumn{7}{|c|}{ 2001-2002 } \\
\hline $\begin{array}{c}\text { Primary } \\
\text { education }\end{array}$ & 9.09 & 56.41 & 46.62 & 35.52 & 36.75 & 32.65 \\
\hline $\begin{array}{l}\text { Secondary } \\
\text { education }\end{array}$ & 10.78 & 24.9 & 32.25 & 32.32 & 28.32 & 28.51 \\
\hline $\begin{array}{l}\text { College and } \\
\text { universities }\end{array}$ & 29.44 & 9.39 & 8.55 & 6.01 & 7.70 & 14.71 \\
\hline Professional & 28.82 & 5.83 & 7.24 & 5.10 & 8.59 & 10.21 \\
\hline \multicolumn{7}{|c|}{$2002-2003$} \\
\hline $\begin{array}{c}\text { Primary } \\
\text { education }\end{array}$ & 8.79 & 57.54 & 45.72 & 41.55 & 36.75 & 42.4 \\
\hline $\begin{array}{l}\text { Senalcondar } \\
\text { y education }\end{array}$ & 11.94 & 24.27 & 33.81 & 35.73 & 28.32 & 25.81 \\
\hline $\begin{array}{l}\text { College and } \\
\text { universities }\end{array}$ & 46.59 & 9.77 & 9.23 & 3.09 & 8.43 & 15.52 \\
\hline Professional & 16.92 & 5.17 & 6.36 & 3.42 & 11.86 & 7.73 \\
\hline \multicolumn{7}{|c|}{ 2003-2004 } \\
\hline $\begin{array}{c}\text { Primary } \\
\text { education }\end{array}$ & 7.83 & 60.14 & 43.08 & 44.88 & 34.88 & 44.32 \\
\hline $\begin{array}{c}\text { Secondary } \\
\text { education }\end{array}$ & 10.25 & 21.35 & 32.61 & 38.52 & 29.66 & 24.00 \\
\hline $\begin{array}{l}\text { College and } \\
\text { universities }\end{array}$ & 50.81 & 7.30 & 8.26 & 7.14 & 6.83 & 15.27 \\
\hline Professional & 13.76 & 4.65 & 6.11 & 4.93 & 7.37 & 6.74 \\
\hline \multicolumn{7}{|c|}{ 2004-2005 } \\
\hline $\begin{array}{c}\text { Primary } \\
\text { education }\end{array}$ & 11.46 & 57.6 & 42.91 & 45.84 & 30.66 & 42.18 \\
\hline $\begin{array}{c}\text { Secondary } \\
\text { education }\end{array}$ & 8.81 & 21.56 & 33.41 & 41.3 & 24.44 & 23.46 \\
\hline $\begin{array}{l}\text { College and } \\
\text { universities }\end{array}$ & 28.70 & 7.88 & 8.93 & 6.22 & 6.35 & 12.31 \\
\hline Professional & 40.54 & 4.49 & 6.85 & 4.97 & 7.79 & 12.97 \\
\hline \multicolumn{7}{|c|}{ 2005-2006 } \\
\hline $\begin{array}{c}\text { Primary } \\
\text { education }\end{array}$ & 5.47 & 55.06 & 39.73 & 45.71 & 30.43 & 37.99 \\
\hline $\begin{array}{l}\text { Secondary } \\
\text { education }\end{array}$ & 7.82 & 23.18 & 32.87 & 45.14 & 26.85 & 23.89 \\
\hline $\begin{array}{l}\text { College and } \\
\text { universities }\end{array}$ & 59.10 & 8.73 & 10.29 & 6.17 & 6.93 & 20.62 \\
\hline Professional & 13.12 & 5.17 & 6.13 & 5.31 & 9.79 & 7.47 \\
\hline
\end{tabular}




\section{Macrothink}

International Journal of Accounting and Financial Reporting ISSN 2162-3082 2012, Vol. 2, No. 1

The most important contribution in increased budget allocation is by the Punjab Education Sector Reform Programme (PESRP). The investment in education started to rise in 2003. The total expenditure on education tripled from Rs. 9200 million in 2005-2006 to Rs. 21480 million in 2007-2008. Most of the budget invested in the education sector was allocated to the primary level and as a result an increase in the enrollment rate of the primary students takes place (Ahmad, 2009).

\begin{tabular}{|c|c|c|c|c|c|}
\hline \multicolumn{6}{|c|}{ Allocation of budget to education sector and percentage change } \\
\hline \multirow{2}{*}{$\begin{array}{c}\text { Education } \\
\text { budget }\end{array}$} & \multirow{2}{*}{$\begin{array}{c}\text { 2008/2009 } \\
\text { budget }\end{array}$} & \multirow{2}{*}{$\begin{array}{c}2008 / 2009 \\
\text { expenditure }\end{array}$} & \multirow{2}{*}{$\begin{array}{c}2009 / 2010 \\
\text { budget }\end{array}$} & \multicolumn{2}{|c|}{ Percentage change } \\
\hline & & & & Budget & Expenditure \\
\hline Total & $22,521.63$ & $29,140.37$ & $21,267.17$ & $-6 \%$ & $-27 \%$ \\
\hline Salary & $9,235.27$ & $9,300.21$ & $11,236.39$ & $22 \%$ & $21 \%$ \\
\hline Non-salary & $13,286.36$ & $19,840.16$ & $10,030.78$ & $-25 \%$ & $-49 \%$ \\
\hline \multicolumn{6}{|c|}{ Source: Institute of Social and Policy Sciences, 2009} \\
\hline
\end{tabular}

Pakistan allocates lowest budget to education sector. Public expenditure to education is lowest part of the GDP as compared to other South Asian countries. Pakistan allocates 2.24\% GDP in 2005-2006. Then there was an increase in the budget allocation by the government in 2006-2007 which was 2.50\% of the GDP. After that government allocated $2.47 \%$ GDP in 2007-2008. Subsequently in 2008-2009 the government allocated 2.10\% GDP to increase the literacy rate. In 2009-2010 the budget allocation GDP is $2.05 \%$. Thus budget allocation became lesser in the later years after 2005-2006 (Economic Survey of Pakistan, 2010).

\begin{tabular}{|c|c|c|c|}
\hline \multicolumn{3}{|c|}{ Summary of public sector budget allocation for education 2009-2010 (Rs. in millions) } \\
\hline \multicolumn{3}{|c|}{ Federal governments } \\
\hline Federal government & Current & Development & Total \\
\hline Ministry of Education & 3718.665 & 5500.000 & 9218.655 \\
\hline Higher education commission & 21500.000 & 18500.000 & 44000.000 \\
\hline $\begin{array}{c}\text { Federal government education institution in } \\
\text { Cantonment and Garrisons }\end{array}$ & 1929.760 & 14.910 & 1944.670 \\
\hline Federally administered tribal areas & 4143.716 & 1534.318 & 5678.034 \\
\hline Gilgat Baltistan & 1408.738 & 784.081 & 2192.819 \\
\hline AJ \& K & 3794.450 & 722.000 & 4516.450 \\
\hline $\begin{array}{c}\text { Social welfare and special education } \\
\text { commission }\end{array}$ & 410.340 & 316.450 & 726.790 \\
\hline National, vocational and technical education \\
commission
\end{tabular}




\section{Macrothink}

International Journal of Accounting and Financial Reporting ISSN 2162-3082

\begin{tabular}{|c|c|c|c|}
\hline Government of Khyber Pakhtunkhwa & 2411.730 & 2421.133 & 4832.863 \\
\hline Government of Baluchistan & 2008.985 & 6059.354 & 8068.339 \\
\hline Total (Provinces) & 43118.503 & 39295.076 & 82413.579 \\
\hline \multicolumn{4}{|c|}{ District government } \\
\hline Punjab & 66223.058 & 6293.739 & 72516.797 \\
\hline Sind & 31930.127 & 5714.157 & 37664.284 \\
\hline Khyber Pakhtunkhwa & 21379.271 & 1995.678 & 23374.949 \\
\hline Baluchistan & 8673.374 & 102.460 & 8775.834 \\
\hline Total districts governments & 128205.830 & 14106.034 & 142311.864 \\
\hline Total provinces and district governments & 171324.333 & 53401.110 & 224725.443 \\
\hline $\begin{array}{l}\text { Grand total federal, provisional and district } \\
\text { governments }\end{array}$ & 215026.555 & 85936.200 & 300962.755 \\
\hline \multicolumn{4}{|c|}{ Source: Ministry of Education published in Pakistan Economic Survey, 2010.} \\
\hline
\end{tabular}

Education endow with strong base for the socio-economic development of any country. An education system of poor quality may be one of the most important rationales why poor countries like Pakistan do not develop (Filmer and Prittchet, 2001). There are many barricades in education sector like disparities between region and gender, lack of trained teachers, deficiency of proper teaching materials, poor physical infrastructure of schools, low levels of public investment in primary education sector, allocation of government funds towards higher education and movement of highly educated people to developed countries for higher education or in search of better job opportunities (Checchi, 2003). Other blockades are acute shortage of teachers, poorly equipped laboratories, little relevance of curriculum to present day needs, cheating in examinations, overcrowded classrooms and lack of adequately trained master trainers (Memon, 2007).

Globally, educating a nation remains the vital strategy for the development of third world countries (Aikaman \& Unterhalter, 2005). Numerous studies on human capital development concur that it is the human resources of a nation (and not its capital or natural resources) that ultimately determine the pace of its economic and social development. The principal institutional mechanism for developing human capital is the formal education system of primary, secondary and tertiary training (Nsubuga, 2003). Because child labor, deprivation from schooling, dispossession from adult employment and augmented fertility rate depends upon decision making of the household to educate their children (Leech and Little, 1999). The researcher has pointed out that every child has been engaged in one of the three activities at the age of 5-14 either he is at school, working at workplace or physically disabled (Deininger, 2003). Dropout rates of the children may be one of the determinants of child labor. Additional determinant is poor household with low adult employment. This determinant will tend to keep their children back from school and these households will have higher demand for children to provide child labor to earn additional income for their households (Mahmood, et al. 1994).

There are many factors that can reduce child labor such as enhanced access to school, provision of incentives and reduction in schooling costs. It may raise the school attendance 


\section{MInstitute Macrothink $^{m}$}

International Journal of Accounting and Financial Reporting ISSN 2162-3082 2012, Vol. 2, No. 1

and thus becomes the major economic factor to reduce child labor. The researcher pointed out two major types of child labor in Pakistan (Boyle, 2002). One is child labor within the household (Intrahousehold child labor) and other is child work in the labor market (Extrahousehold child labor). They both have an impact on schooling access of rural areas of Pakistan. Extrahousehold work is the major motivational factor for the parents for not sending their children to school (Hazarika and Bedi, 2003). Nevertheless there are many economic obstructions in education sector that diminishes its effectiveness for the development of country. These barriers are lack of resources, poor infrastructure, lack of well designed curriculum, underinvestment in education sector and low quality of teachers training (Rehmani, 2010). Quality of education in Pakistan is very low due to wastage of resources, direct cost of schooling and improper infrastructure (Shami, et al. 2005). School uniforms, schools books, low parental income and labor contribution are the cost of schooling that divests the children from getting quality education (Hopper, 1991).

Gender inequality is widespread in resisting the process of development in Pakistan. There are numerous factors that contribute to lack of access of women to education sector like lack of incentives for parents who educate their daughters, deficiency of proper infrastructure, low quality education, cost of schooling, public private divide in education sector and institutional weakness (Andrabi, et al. 2007). Regardless of these economic determinants low adult literacy rate, low enrollment rate, high dropout rate, high cost of schooling, parental disinterest in educating their children, lack of proper school infrastructure, economic insecurity for teachers and low quality education are the major barricades that have negative impact on literacy rate of Pakistan (Aly, 2007). Other constraints are squat socio-economic status of the parents that limited the access of girls to education sector, lack of proper school arrangements that is attributed to lack of improper school infrastructure and proximity of the schools. Shortage of girls schools, poor quality teachers training, teachers absenteeism, weak curriculum and low quality education are the foremost obstacles to girls education (Qureshi, 2004).

During the past fifteen years the ratio of female to male population has increased but the endeavors to improve the female life quality and their contribution to education and economic development is still low (Siddique, 2001). Accordingly the female literacy rates and access to education is also low. These findings demonstrates that like the other developing countries in South Asia the status of human resources is low despite the expansion in health and education infrastructure (Brown, 2006).

\section{Purpose of the Study:}

The current situation of education/literacy in the country is pathetic and diverse economic impediments are needed to be addressed. This research intends to understand the current situation of literacy rate in Pakistan and analyze various economic obstructions that are hampering the process of development in education sector of Pakistan (especially in context of Southern Punjab). Although some researches are conducted on various underlying issues that are related with economic sphere that incorporate lack of manpower, lack of proper school infrastructure and non-availability of learning materials. Alternatively deficient 
salaries for teachers, inadequate coordination between planning and implementation; lack of coordination between national education ministry, provincial ministries and local bodies; lack of sufficient budgetary allocation to education sector, cost of schooling as well as child labor are the major economic impediments that have significant negative impact on education sector of Southern Punjab (Pakistan). This research is exceptional in addressing these issues in general in context of Southern Punjab (Pakistan). The identification of these variables endow with an enhanced understanding about various aspects of the research especially related with economic impediments. The researcher cracks down on the following research questions during the course of present study:

1. What are the major economic impediments in structure of education sector of Southern Punjab (Pakistan)?

2. To what extent these economic impediments are hampering the process of development in education sector of Southern Punjab (Pakistan)?

3. What are the recent chronic trends of budget allocation by the government in education sector of Southern Punjab (Pakistan)?

4. What are the major implications of these budget trends on literacy rate of Pakistan?

5. What are the major policy implications for this issue?

\section{Methodology:}

Data was collected from the students enrolled in class $10^{\text {th }}$ of affiliated schools from Board of Intermediate and Secondary Education (BISE). All the students, their parents and teachers from affiliated schools from BISE were the universe while the students enrolled in grade $10^{\text {th }}$ were the target population. A sample size of $\mathrm{N} 1=600$ respondents $(\mathrm{n} 1=200$ students, $\mathrm{n} 2=200$ parents and n3=200 teachers) were selected through multistage sampling technique. Two districts (Multan districts and Vehari district) were selected from Multan division through simple random sampling technique in the first stage of sample selection. Then $n 4=20$ schools were selected from Vehari district and n5=30 schools were selected from Multan district (a grand total of N2=50 schools) through systematic random sampling technique in the second stage of multistage sample selection. Afterward the researcher selected an average of 3-6 students from $10^{\text {th }}$ grade of each school by the application of law of large number in which the bigger sample is selected from the bigger part of the population and the smaller sample is selected from the smaller part of the population. Interview schedule was used as a tool for data collection procedure. Both structured and unstructured questions were used to evaluate the relationship among the study variables. The foremost purpose behind using both the open ended and close ended questions were to maximize the response rate. The researcher had to face many constraints in terms of biased responses of the respondents but the researcher tried to avoid the response errors to the maximum level. Data was coded by using SPSS software (version 17) and the relationship was established among the dependent (effect) and independent (cause) variables. Then the researcher analyzed the data through ANOVA test application. The formula for one way ANOVA is as follows: 


$$
\begin{aligned}
& S S_{\text {total }}=\left(\sum x_{1}{ }^{2}+\sum x_{2}{ }^{2}+\ldots \sum x_{r}{ }^{2}\right)-\frac{\left(\sum x_{1}+\Sigma x_{2}+\sum x_{r}\right)}{N} \\
& S S_{\text {total }}=\left[\frac{\left(\sum x_{1}\right)^{2}}{n_{1}}+\frac{\left(\sum x_{2}\right)^{2}}{n_{2}}+\ldots \frac{\left(\sum x_{r}\right)^{2}}{n_{r}}\right]-\frac{\left(\sum x_{1}+\sum x_{2}+\ldots \Sigma x_{r}\right)}{N} \\
& S S_{\text {within }}=S S_{\text {total }}-S S_{\text {among }} \\
& d f_{\text {among }}=\mathrm{r}-1 \quad d f_{\text {within }}=\mathrm{N}-\mathrm{r}
\end{aligned}
$$

$M S_{\text {among }}=\frac{S S_{\text {among }}}{d f_{\text {among }}}$

$F=\frac{M S_{\text {among }}}{M S_{\text {within }}}$

$\mathrm{x}=$ individual observation

$r=$ number of groups

$\mathrm{N}=$ total number of observations (all groups)

$\mathrm{n}=$ number of observations in group

\section{Results and Analysis:}

\section{Determinants}

\begin{tabular}{|c|c|c|c|}
\hline \multirow{2}{*}{ Variables } & \multicolumn{3}{|c|}{ Percentage of respondents who agreed on } \\
& \multicolumn{3}{|c|}{ this stance } \\
\cline { 2 - 4 } & Teachers & Students & Parents \\
\hline Corruption & $66.5 \%$ & $43.5 \%$ & $28 \%$ \\
\hline Inflation & $51 \%$ & $42 \%$ & $70.5 \%$ \\
\hline Limited family earnings & $68.5 \%$ & $79 \%$ & $34.5 \%$ \\
\hline Lack of resources & $78 \%$ & $59.5 \%$ & $47 \%$ \\
\hline Wastage of resources & $75 \%$ & $54.5 \%$ & $48.5 \%$ \\
\hline Non-participation from private sector & $64.5 \%$ & $72.5 \%$ & $82.5 \%$ \\
\hline Inadequate school infrastructure & $54.5 \%$ & $76 \%$ & $57 \%$ \\
\hline Direct cost of schooling & $61 \%$ & $54.5 \%$ & $73.5 \%$ \\
\hline School fee & $58.5 \%$ & $67 \%$ & $81.5 \%$ \\
\hline Intrahousehold child labor & $70 \%$ & $55.5 \%$ & $28.5 \%$ \\
\hline Extrahousehold child labor & $74.5 \%$ & $61 \%$ & $32.5 \%$ \\
\hline
\end{tabular}




\begin{tabular}{|c|c|c|c|}
\hline Lack of future economic security for teachers & $86.5 \%$ & $52 \%$ & $16.5 \%$ \\
\hline Overcrowded classes & $67.5 \%$ & $75.5 \%$ & $45 \%$ \\
\hline Lack of libraries & $64.5 \%$ & $72 \%$ & $45 \%$ \\
\hline Lack of laboratories & $70 \%$ & $73.5 \%$ & $49.5 \%$ \\
\hline Lack of research facilities & $62.5 \%$ & $77 \%$ & $54 \%$ \\
\hline Low budget allocation by the government & $83 \%$ & $57.5 \%$ & $48.5 \%$ \\
\hline Lack of stakeholders participation & $52 \%$ & $63.5 \%$ & $32 \%$ \\
\hline Lack of public private partnership & $51.5 \%$ & $41 \%$ & $63 \%$ \\
\hline Inadequate shift of resources between subsectors & $48 \%$ & $32 \%$ & $14.5 \%$ \\
\hline Lack of qualified manpower & $23 \%$ & $57.5 \%$ & $34 \%$ \\
\hline Widening the structural divide & $62.5 \%$ & $71.5 \%$ & $51 \%$ \\
\hline
\end{tabular}

\section{Discussion:}

Quality and improved schooling is the base for development planning and this is controversial nowadays because school quality and expansion does not perk up economic expansion (Hanushek and Woessmann, 2007). The researcher concluded that education quality is indispensable in promoting economic well being of the individuals. There is a strong verification that convalesce schooling does not plays a vital role in economic well being of the individual but cognitive skills of the population is directly narrated to economic growth, individual earnings and allocation of income towards education sector (Brown, 2006). The skill development and quality of educational institutions escort towards high economic growth. In developing countries the deficit skill development leads towards less economic growth. If the economic gap between the countries is reduced then the education system requires the major structural changes and they must focus on the cognitive skill development of the individuals (Vachon, 2007). Additional blockades are lack of government obligation to education sector, inadequate allocation of resources to education sector, shifting resources between public and private sectors, inadequate resource mobilization, inadequate shift of resources between subsectors, misplaced budget priorities and neglection of government to primary education in terms of budget allocation of resources (Filmer, 2007). There are assorted stumbling blocks in education sector like overcrowded classes, absence of basic classroom materials, lack of drinking water and sanitary facilities.

School level blockades include no school close to home, poor quality environment e.g. poor condition of buildings, overcrowded classes, lack of portable water availability, poor sanitation system as well as physical and psychological violence (Noorani, 2009). Pertaining to the above revealed discussion the above mentioned table no. 1 also cited that $48 \%$ teachers, $32 \%$ students and $14.5 \%$ parents agree that (inadequate shift of resources between subsectors) and $67.5 \%$ teachers, $75.5 \%$ students and $45 \%$ parents agree that (overcrowded classes) are the 


\section{MInstitute Macrothink $^{m}$}

International Journal of Accounting and Financial Reporting ISSN 2162-3082 2012, Vol. 2, No. 1

major economic impediments that are hampering the process of development in education sector of Southern Punjab (Pakistan). There are diverse blockades in education sector like overcrowded classes, absence of basic classroom materials, lack of drinking water, lack of sanitary facilities and inappropriate teachers training (Vachon, 2007). Therefore education system is not in a position to manage the learning outcomes especially in the literacy, numeracy and life skills. Gender discrimination, rural urban gap, teachers absenteeism, inadequate attention of teachers to every student and lack of teachers availability are the foremost determinants that leads to various economic impediments (PRSP, 2003).

The key learning constraints include low economic status of the parents, low parental education, cultural barriers, weak teachers performance, lack of accountability and insufficient instructional time. Demand side constraints include poor families, low levels of parental literacy and linguistic differences. The major teachers side constraint is low level of motivation and incentives for teachers (Groppela, 2003). Accompanying impediments include lack of supervision, lack of inspection systems, low teachers salaries and job insecurity for teachers $(86.5 \%$ teachers, $52 \%$ students and $16.5 \%$ parents agree on this stance as the major economic impediment in education sector of Pakistan), insufficient teachers training, lack of teachers qualification and decentralized system of teachers monitoring (Anderson and Dexter, 2005). The literacy rate of Pakistan is very low especially Southern Punjab ranks lowest in literacy rate. Government is not able to invest more on education sector. The population of Pakistan is growing at the faster pace but the investment in education sector is not in an adequate amount. Government allocation of education budget is not sufficient to meet the needs of education sector (Memon, 2007). Other economic impediments include the official fees and the second category includes the extensive range of factors like household budgets, cost of textbooks, school uniforms, school fees and various other educational expenditures (Leech and Little, 1999).

Other economic impediments are also significant like low proportion of revenue allocation to education sector, low share of education budget to basic education, lack of government obligation to education sector, derisory allocation of resources to education sector, shifting resources between public and private sectors, misplaced budget priorities and neglection of government to primary education in terms of budget allocation of resources (Ajuoga, 2000). Government allocation of education budget is not sufficient to meet the needs of education sector. This budget lags behind the other South Asian countries. Due to this lag the development rate of Pakistan is far below the other third world countries (Ahmad, 2009).

Thus the above cited table shows that $83 \%$ teachers, $57.5 \%$ students and $48.5 \%$ parents agree that lack of budget allocation to education sector is the major economic impediment in education sector of Pakistan. Dropout rates of the children may be one of the determinants of child labor. Other determinant is poor household with low adult employment. This determinant will tend to keep their children back from school and these households will have higher demand for children to provide Intrahousehold child labor to earn additional income for their households (Mahmood, et al. 1994). Thus the above mentioned table illustrates that $70 \%$ teachers, $55.5 \%$ students and $28.5 \%$ parents agree that Intrahousehold child labor is the major determinant of drop out of students from school. They both have an impact on 


\section{Mll Macrothink}

International Journal of Accounting and Financial Reporting ISSN 2162-3082 2012, Vol. 2, No. 1

schooling access of rural areas of Pakistan. Extrahousehold work is the major motivational factor for the parents for not sending their children to school (Hazarika and Bedi, 2003). Accordingly $74.5 \%$ teachers, $61 \%$ students and $32.5 \%$ parents agree that Extrahousehold child labor is the major economic impediment associated with education sector of Southern Punjab (Pakistan). There are many factors that can reduce child labor such as enhanced access to school, provision of incentives and reduction in schooling costs. It may raise the school attendance and thus becomes the major factor to reduce child labor (Mansuri, 2006).

However in poor countries the state provision is privatized through cost sharing and transfer of financing responsibility from national budgets to household budgets. Government investment on education can be increased through reallocation of resources. School fees is the major determinant of school completion and it is the direct cost of schooling that has the negative influence upon the enrollment rate of the students (Deininger, 2003). Accordingly $58.5 \%$ teachers, $67 \%$ students and $81.5 \%$ parents agree that school fees is the major economic impediment that deprives the students from schooling. On the other hand lack of political will, weak implementation of educational laws as well as direct cost of schooling are the major economic barricades of development in education sector (Boyle, et al. 2002). Increase in educational expenses comprises of direct cost of schooling that is the major rationale of high dropout rate of children particularly of the girls because this direct cost of schooling is out of affordance for the poor families (Malik, 2002). Therefore $61 \%$ teachers, $54.5 \%$ students and $73.5 \%$ parents agree that direct cost of schooling is the major economic impediment that is responsible for low enrollment rate of the students. In addition to this Andrabi, et al. (2007) concluded that school fees, school uniforms, school books and school shoes are the direct cost of schooling that results in high dropout rates of the students. On the other hand gender discrimination with girls, traditional prejudices and gender role stereotypes are the indirect cost of schooling that contributes to low enrollment rates of the students. In Pakistan parents prefer to educate their sons than their daughters. This gender discrimination in the investment of education is due to limited family earnings and income volatility (Sawada, 1997).

There are countless determinants of girls and boys schooling. Grade attainment, current enrollment rate, withdrawal from school and various household effects are the major determinants of school completion for both boys and girls (Glick and Sahn, 2000). Increase in household income has positive impacts on girls schooling but has no impact on boys schooling because boys are already preferred over girls even when investment is low in case of education (Behraman and Knowles, 1999). There is a strong relationship between household income and child schooling. Less intergenerational mobility leads to less attainment of educational opportunities (Glewwe and Kremer, 2005). Nevertheless sometimes gender differentiations influence the issue because the parents prefer to invest more on boys education than girls education because it is mostly admitted that boys education is a necessity and girls education is a luxury. Therefore $68.5 \%$ teachers, $79 \%$ students and $34.5 \%$ parents agree that limited family earnings is the major determinant of preference for boys education over girls education. Pakistan, India, Nepal and Indonesia have strong influence of household wealth on student enrollment in the school because family wealth have strong and direct 
influence on per capita output and poverty (Filmer and Pritchett, 2001).

The researcher found that there is a strong alliance between family wealth and enrollment rate of children. When family income increases then parents afford direct cost of schooling and willing to send their children to school (Aslam, 2009). There are several factors that becomes the hurdle in the implementation of any education policy and they comprise absence of whole education sector view, lack of policy coherence in education sector, unclear roles of fragmented government, parallel systems of education (public-private divide), widening the structural divide, weak educational planning, weak management and lack of stakeholders participation (Bynner and Parsons, 1997). Accordingly 62.5\% teachers, 71.5\% students and $51 \%$ parents agree on this stance that widening the structural divide is the major economic impediment related with education sector of Southern Punjab (Pakistan). On the other hand the researcher also focused on other economic impediments and they include lack of resources and wastage of resources (Rehman, 2005). Quality of education in Pakistan is very low due to wastage of resources, grade repetitions and high dropout rates of the students. Due to this resource depletion the budget allocation and the financial resources of the education sector are not able to meet the educational expenses. Thus the above mentioned table demonstrates that $78 \%$ teachers, $59.5 \%$ students and $47 \%$ parents agree that lack of resources is the major economic impediment that plays a vital role in decreasing the literacy rate of Pakistan. On the other hand a simultaneous economic impediment in education sector is also the wastage of resources. These material constraining factors that influence the school performance include lack of well furnished school buildings, inadequate resources, lack of well designed curriculum and non-manageable class size (Shami, et al. 2005). Thus 75\% teachers, $54.5 \%$ students and $48.5 \%$ parents agree that wastage of resources is the major economic impediment that is responsible for weak performance of education sector in Pakistan.

There are other multidimensional problems of the country like lack of resources, non-participation from private sector (64.5\% teachers, $72.5 \%$ students and $82.5 \%$ parents), scarcity of the qualified manpower (23\% teachers, $57.5 \%$ students and $34 \%$ parents), inconsistency in the policies of various regimes, political instability, insufficient education management system, wastage of resources and poor implementation of educational policies (Barnet, 1990). There are numerous barriers and disputes that have to be faced by the developing countries. There is always lack of institutional arrangements and also financial constraints. Developing countries have to face many constraints regarding education sector because they cannot face the challenges of unpredictable global economy due to budget constraints (Rasian, 2009). The researcher concluded the work of Robertson (2009) and World Bank (2007) to analyze the economic challenges and barriers regarding higher education in developing countries. There are three foremost factors that constraints the education growth in Pakistan (such as poor state of government, poor state of institutions and lack of competitive environment that restricts the innovation process). Accordingly there are numerous barriers such as government failure, institutional shortcomings, corruption $(66.5 \%$ teachers, $43.5 \%$ students and $28 \%$ parents) and inadequate juridical independence that hamper the process of development in education sector of Pakistan. Despite this fact 
education institutions do not supply adequate skilled labor force that is the major stumbling block in the process of development in Pakistan (Qayyum, et al. 2008).

There are diverse factors that contribute to disappointing performance of Pakistan such as excessive defense spending, weak government performance, corruption, inflation (51\% teachers, $42 \%$ students and $70.5 \%$ parents) government instability, sectarian violence and Kashmir conflict. Elementary education provides the opportunities to underprivileged countries to develop (World Development Indicators, 2007). There are countless social evils in the developing countries (like corruption, unemployment, low earnings, inflation, exploitation, rapid population growth and political instability) that lower the literacy rate of Pakistan. South Asian countries have literacy rate of $43 \%$ and the foremost indicators that determine education are sky-scraping (Kazmi, 2005). The most essential investment in human capital is education but education sector of Pakistan is suffering from many barriers that obstruct its process of development. These confronts range from lack of libraries to deficiency of research facilities. Other challenges include underinvestment in education sector, lack of accountability, lack of potential for resource mobilization and high dropout rates of students from Pakistan. There are some other resisting factors in the process of development in education sector of Pakistan. They comprise lack of availability and accessibility of low cost and high quality education, absence of formal criterion for funds allocation at school level, weak policy framework of the government and lack of teachers availability (PRSP, 2003). Thus 54.5\% teachers, 76\% students and 57\% parents agree that inadequate infrastructure is the major barrier that is responsible for low quality education and low enrollment rate of the students to schools. Barriers regarding education include gender in equalization, rigid family decisions to send their daughters to schools, lack of infrastructure, lack of quality education, cost of schooling and proximity from school (Andrabi, et al. 2007).

Developing country like Pakistan has to countenance numerous barricades regarding quality of staff, government intervention, academic standards, libraries development, improvement in laboratories, increase in research facilities and student preparation (Aslam, 2009). Thus $64.5 \%$ teachers, $72 \%$ students and $45 \%$ parents agree that (lack of libraries), $70 \%$ teachers, $73.5 \%$ students and $49.5 \%$ parents agree that (lack of laboratories) and 62.5\% teachers, $77 \%$ students and $54 \%$ parents agree that (lack of research facilities) are the major economic impediments that impedes the process of development in education sector of Pakistan. The researcher pointed out that government intervention is significant regarding higher education but unfortunately very low budget is allocated towards higher education. Education sector has to face lot of confronts like lack of dedication of teachers towards their teaching profession, low quality teaching, inadequate availability of research facilities across higher education and little possibility of international collaboration with other universities (Robertson, 2009).

\section{Hypothesis testing:}

\section{Hypothesis 1:}

Hypothesis: Underinvestment by the government in education sector is the major determinant of low literacy rate. 
Independent variable (Cause variable): Underinvestment by the government (Low budget allocation to education sector)

Dependent variable (Effect variable): Low literacy rate

One-way ANOVA among three stakeholders of education sector (Students, Parents, Teachers)

\begin{tabular}{|l|l|l|l|l|l|}
\hline Source & DF & SS & MS & F & P \\
\cline { 1 - 4 } Factor & 2 & 140.90 & 70.45 & & \multirow{2}{*}{13.84} \\
\cline { 1 - 4 } Error & 596 & 3033.19 & 5.09 & 0.000 \\
\cline { 1 - 4 } Total & 598 & 3174.10 & & & \\
\hline
\end{tabular}

\section{Discussion:}

As the researcher evaluated the responses of three major stakeholders in education sector (parents, teachers and students) therefore the researcher used ANOVA test for this purpose. Since 1947 every year the budget allocation to education sector diminishes or remains constant. Mostly the government allocates 2\% GDP to education sector of Pakistan. Other issues in this regard are dissimilar sectors of educational institution that needs different budgets. As mentioned by Memon (2007) government is not able to invest more on education sector. The population of Pakistan is growing at the faster pace but the investment on education sector is not in an adequate amount. Education is the fundamental investment in human capital formation. Therefore the researcher made this hypothesis to enhance the vital obstruction of low budget allocation by the government to education sector of Pakistan. As mentioned by Ahmad (2009) government spending on education increases in recent years. The most important contribution in increased budget allocation is by Punjab Education Sector Reforms Programme (PESRP).

\begin{tabular}{|c|c|c|c|c|}
\hline \multicolumn{5}{|c|}{ Year wise budget allocation to education sector of Pakistan } \\
\hline Year & Recurring budget & $\begin{array}{c}\text { Development } \\
\text { budget }\end{array}$ & $\begin{array}{c}\text { Total education } \\
\text { budget }\end{array}$ & \% of GDP \\
\hline $\mathbf{1 9 9 5 - 9 6}$ & 39.610 & 2.585 & 42.195 & 2.00 \\
\hline $\mathbf{1 9 9 6 - 9 7}$ & 40.536 & 1.968 & 42.504 & 2.62 \\
\hline $\mathbf{1 9 9 7 - 9 8}$ & 46.100 & 2.984 & 49.084 & 2.34 \\
\hline $\mathbf{1 9 9 8 - 9 9}$ & 46.979 & 2.427 & 49.406 & 2.40 \\
\hline $\mathbf{1 9 9 9 - 2 0 0 0}$ & 51.572 & 2.430 & 54.002 & 1.7 \\
\hline $\mathbf{2 0 0 0 - 2 0 0 1}$ & 54.396 & 1.966 & 56.362 & 1.6 \\
\hline $\mathbf{2 0 0 1 - 2 0 0 2}$ & 64.975 & 2.500 & 67.475 & 1.9 \\
\hline $\mathbf{2 0 0 2 - 0 3}$ & 67.270 & 2.604 & 69.874 & 1.7 \\
\hline
\end{tabular}


The investment in education started to rise in 2003. The total expenditure on education tripled from Rs. 9200 million in 2005-2006 to Rs. 21480 million in 2007-2008. Most of the budget invested in the education sector was allocated to the primary level and as a result an increase in enrollment rate of the primary students takes place (Falch and Rattso, 1997). The below mentioned table makes this hypothesis more valid. The table shows that among various South Asian countries Pakistan spend lowest GDP on education sector. Therefore its literacy rate is also lowest among other South Asian countries.

\begin{tabular}{|c|c|c|}
\hline \multicolumn{3}{|c|}{ Comparison of public sector spending on education } \\
\hline Country & $\begin{array}{c}\text { Public sector spending as a } \\
\text { percentage of GDP }\end{array}$ & Literacy rate in percentage \\
\hline Bangladesh & 2.6 & 55.0 \\
\hline China & - & 93.7 \\
\hline India & 3.3 & - \\
\hline Indonesia & 3.5 & - \\
\hline Iran & 5.2 & - \\
\hline Malaysia & 4.7 & 92.1 \\
\hline Nepal & 3.2 & 57.9 \\
\hline Pakistan & 2.1 & 57.0 \\
\hline Sri-Lanka & - & 90.6 \\
\hline Thailand & 4.5 & - \\
\hline Vietnam & 5.3 & 92.5 \\
\hline
\end{tabular}

Public expenditure to education is lowest part of the GDP as compared to other South Asian countries. Pakistan allocates $2.24 \%$ of the GDP in 2005-2006. After that there was an increase in the budget allocation by the government in 2006-2007 which was $2.50 \%$ of the GDP. Subsequently government allocated $2.47 \%$ of the GDP in 2007-2008. Then in 2008-2009 the government allocated $2.10 \%$ of the GDP to increase the literacy rate. In 2009-2010 the budget allocation of the GDP is $2.05 \%$. Thus the budget allocation became lesser in the later years after 2005-2006 (Economic Survey of Pakistan, 2010).

\begin{tabular}{|c|c|}
\hline \multicolumn{2}{|c|}{ Percentage GDP spend on education in various countries } \\
\hline Country & Percentage GDP spend on education \\
\hline Pakistan & $2.3 \%$ \\
\hline Iran & $4.7 \%$ \\
\hline Malaysia & $6.2 \%$ \\
\hline Thailand & $4.2 \%$ \\
\hline South Korea & $4.6 \%$ \\
\hline India & $3.8 \%$ \\
\hline Bangladesh & $2.5 \%$ \\
\hline \multicolumn{2}{|c|}{ Source: World Development Indicators, 2007. } \\
\hline
\end{tabular}

Thus from the above discussion and statistical test the researcher can deduce that underinvestment by the government in education sector has significant impact on literacy rate. 


\section{Macrothink}

International Journal of Accounting and Financial Reporting ISSN 2162-3082

The references shows that lower the GDP spend on education sector by the government lower will be the literacy rate. Thus the $(\boldsymbol{p}=\mathbf{0 . 0 0 0})$ which shows that low budget allocation by the government is the major economic impediment to education sector of Pakistan.

Hypothesis 2: Limited family earnings prefer boys education over girls education.

Independent variable (Cause variable): Limited family earnings

Dependent variable (Effect variable): Preference of boys education over girls/ Gender discrimination with girls enrollment

One-way ANOVA among three stakeholders of education sector (Students, Parents, Teachers)

One-way ANOVA: Students, teachers, parents

\begin{tabular}{|c|c|c|c|c|c|}
\hline Source & DF & SS & MS & $\mathbf{F}$ & $\mathbf{P}$ \\
\hline Factor & 2 & 65.62 & 32.81 & \multirow{3}{*}{18.66} & \multirow{3}{*}{0.000} \\
\hline Error & 597 & 1049.49 & 1.76 & & \\
\hline Total & 599 & 1115.12 & & & \\
\hline
\end{tabular}

\section{Discussion:}

The researcher hypothesize that when there is an issue of investment on children education then the parents prefers boy enrollment in private schools and girls enrollment in public schools. On the other hand when there is limited family earnings then parents prefer boys schooling over girls schooling. Therefore the enrollment rate of girls is far behind than boys. Sometimes limited family earnings deprive both boys and girls from schooling but girls especially become the victim of low socio-economic status of the parents. As mentioned by Watkins (2000) limited family earnings maneuver both at micro level and macro level. At the micro level limited family earnings in households deprive the children from schooling while at the macro level it confines the government spending in education sector. Therefore low socio-economic status of the parents or limited family earnings is the major determinant of low enrollment rate of children. But girls especially become the victim of this determinant. In addition to this quality education is also necessary for enrollment of girls to schools. As mentioned by Qureshi (2004) the most imperative economic impediment related with girls education is limited family earnings because it is the leading rationale for allocating the household funds towards boys education. From the above discussion the researcher concluded that whenever there is an issue of investment on education then boys are always preferred over girls. Thus girls are always been discriminated from access to education sector than boys. As mentioned by Rehman (2005) limited family earning escorts parents to prefer boys schooling over girls schooling. Boys schooling is associated with larger rate of returns as compared to girls schooling. Accordingly the researcher come to the conclusion that when 
girls have been deprived from completing education then this will have the negative impact on economic growth of the country (Kochar, 2004). Therefore girls are always considered as the marginalized component of the society and due to the fear of lower rate of returns girls have always been sidelined in school enrollment. There always exists gender gap in education sector because boys are more preferred to accomplish education than girls (Klasen, 2002). This gender equality has greater impacts on economic growth of country. The main reason is that the average level of human capital lowers because the gender equality leads to low investment on education and thus unskilled labor effects the economic growth of the country. Miscellaneous stumbling blocks related with girls education are mostly concerned with cultural and economic constraints (Glick and Sahn, 2000).

Girls are deprived from decision making about education and thus have little contribution in the economic sharing (because education attainment is directly related with economic sharing process) (Behraman and Knowles, 1999). Therefore girls have low enrollment rate as compared to boys. There are three major areas in education sector that should be explored because they have the dramatic effect on primary school access, type (private verses public) and quality of education because these factors influence the parental decisions to enroll their children to school or not (Lloyed, et al. 2005). Gender discrimination also prevails in educational sector because quality of girls education in schools is the important feature that influences the decision making of the parents to enroll their girls to school but for the boys quality does not matter because parents are already more focused on boys education than girls education (Suryadarma, et al. 2006). On the other hand financial resources are also important. Accordingly financial resources will decide that whether girls have to enroll in schools or not. These differences occur due to differences of parental preference for their daughters and sons (where sons got larger preferences in education than their daughters). Domestic responsibilities have negative impacts on girls education as compared to boys education. Thus $(\boldsymbol{p = 0 . 0 0 0 )}$ and the alternate hypothesis is accepted and the null hypothesis is rejected. Thus the researcher concluded that limited family earning (an imperative economic impediment) is the major determinant of parental preference for boys schooling than girls schooling. Thus family income and probability of schooling are interrelated to each other because school fees and other expenditures narrated to school are only affordable by small population.

\section{Hypothesis 3}

Hypothesis: Direct cost of schooling is the major determinant of high dropout rates among the students.

Independent variable (Cause variable): Direct cost of schooling

Dependent variable (Effect variable): Dropout rates among the students 
One-way ANOVA: students, teachers, parents

\begin{tabular}{|l|l|l|l|l|l|}
\hline Source & DF & SS & MS & F & P \\
\cline { 1 - 4 } Factor & 2 & 262.29 & 131.15 & & \\
\cline { 1 - 4 } Error & 597 & 840.37 & 1.41 & \multirow{2}{*}{93.17} & \multirow{2}{*}{0.000} \\
\cline { 1 - 4 } Total & 599 & 1102.66 & & & \\
\hline
\end{tabular}

\section{Discussion:}

The researcher hypothesize that there is greater impact of cost of schooling on dropout rates of students in schools. There are many obstructions that contribute to high dropout rates of the students. Parental carelessness, increase in educational expenses and non-instantaneous advantages from education sector are the major causes of high dropout rate of students (Glewwe and Kremer, 2005). Child mental weakness is also the factor. Income of household is the important determinant of school completion and increased enrollment rate of students. Due to lack of schools children are slot in child labor and various employment opportunities. Public primary schools significantly amplify the likelihood of dropout rates because they are not able to provide necessary educational skills to the students. Thus the acquisition of the skills will have positive impact on cognitive skills and thus improves the quality of education which will boost the enrollment rate of the students. Direct cost of schooling is also the foremost economic impediment in the development of education sector and this can be divided into two categories. The foremost category includes the official fees and the second category includes the extensive range of factors like household budgets, cost of textbooks, school uniforms and school fees (Watkins, 2000). Other barricades are lack of low government obligation to education sector and shifting resources between public and private sectors and inadequate resource mobilization (Kennedy and Baxter, 2000). The researcher portrays a relationship between two variables. The researcher hypothesize that there is a significant relationship among direct cost of schooling and high dropout rates among the students. There are many obstructions in education sector that encumbers the process of development and they include two foremost areas such as direct cost of schooling (e.g. school fees, school uniforms, school shoes and school books) and indirect cost of schooling (e.g. traditional, cultural and religious beliefs; gender stereotypes associated with girls education, lack of knowledge on benefits of education and gender differences) (Noorani, 2004). Afterward the researcher had taken the responses of the three stakeholders (parents, students and teachers). After this the researcher applied ANOVA test on this hypothesis. There are many supply and demand side barriers that have the momentous impact on education sector. These barriers incorporate various socio-cultural and economic factors such as inclination of boys education over girls education, poverty, direct and indirect cost of schooling (such as school fees, school uniforms and school books) transportation issues, opportunity costs verses lower rate of returns (Addy, 2008). Direct cost of schooling is the major determinants of high dropout rates among the students (Boyle, et al. 2002). The foremost factor behind this is low 


\section{MInstitute ${ }_{\text {Mmk }}^{\text {Macrothink }}$}

International Journal of Accounting and Financial Reporting ISSN 2162-3082 2012, Vol. 2, No. 1

socio-economic status of the parents that cannot afford the direct cost of schooling. School uniforms, schools books, low parental income and labor contribution are the cost of schooling that deprives the children from getting quality education (Hopper, 1991). Poverty is the major determinant of school completion of children. The results of the hypothesis shows that null hypothesis is rejected. Null hypothesis depicts that there is no association between direct cost of schooling and dropout rates of the students. On the other hand alternate hypothesis is accepted which says that direct and indirect cost of schooling is directly associated with high dropout rates of the students. Thus $(\boldsymbol{p}=\mathbf{0 . 0 0 0})$ that this association to be perfectly interrelated.

\section{Conclusion:}

Developing countries like Pakistan have to face many economic impediments in education sector due to unpredictable global economy. There are other multidimensional problems of the country like lack of resources, non-participation from private sector, scarcity of the qualified manpower, inconsistency in the policies of various regimes, political instability, insufficient educational management system, wastage of resources and poor implementation of educational policies. There are auxiliary economic impediments faced by Pakistan like lack of resources, non-participation from private sector, scarcity of the qualified manpower, inconsistency in the policies of diverse regimes, political instability, insufficient education management system, wastage of resources and poor implementation of educational policies. There is always an alliance between income inequality and allocation of resources. Thus direct cost of schooling, opportunity cost of schooling, gender factors, child labor, limited family earnings and inflation are the major factors that deprive the children from educational access. All these factors interact permanently to dispossess the children from schooling. The role of government in provision of equal employment opportunities is also crucial. Nevertheless in poor countries the state provision is privatized through cost sharing and transfer of financing responsibility from national budgets to household expenditures. Other stumbling blocks are also important like lack of government obligation to education sector, inflation, corruption, lack of stakeholders participation, lack of qualified manpower, shifting resources between public and private sectors, inadequate resource mobilization and misplaced budget priorities are the foremost economic impediments that have negative impact on education sector of Southern Punjab (Pakistan).

\section{Policy implications:}

1. Government should allocate funds both at the regional and provincial level on equality basis.

2. Government should allocate funds on the equivalent basis without the discrimination of rural and urban areas.

3. Government should be fully dedicated and committed to increase the literacy rate.

4. Government should diminish rural urban discrimination of education.

5. Government should eradicate the school fees predominantly at the primary level.

6. Government should encourage parents and reward their efforts regarding their 


\section{Macrothink \\ International Journal of Accounting and Financial Reporting \\ ISSN 2162-3082 2012, Vol. 2, No. 1}

children academic achievement.

7. Government should encourage research projects and their critical analysis in education sector so that sufficient data can be collected for the policy makers in education sector of Pakistan.

8. Government should encourage the role of NGO's in provision of educational services to maximum population.

9. Government should ensure future economic security and incentives for the teachers so that they can work without any uncertainty.

10. Government should ensure participation from the private sector so that the uniformity in education sector can be attainment.

11. Government should focus on increasing the number of schools so that parents and students have an easy access to education sector at least at the primary level.

12. Government should give maximum funds to establish laboratories, libraries and research centers in every school.

13. Government should give some incentives so that stakeholders participation can be amplified in education sector of Pakistan.

14. Government should implement policies that can give administrative autonomy and uniformity to education sector which is the only way to achieve quality education in Pakistan.

15. Government should perk up enrollment rate of the students by reducing the direct and indirect cost of schooling.

16. Government should perk up school reformations and ensure improvement in the school infrastructure of Pakistan.

17. Government should improve the infrastructural facilities like clean water, roads, boundrywall, toilets and lightening.

18. Government should augment welfare services so that the poor families should focus on educational attainment of their children.

19. Government should commence positive competition between the state schools and private schools so that both can contribute to increase the literacy rate of Pakistan.

20. Government should make improvement in internet availability.

21. Government should make improvement in library construction and organization.

22. Government should make improvement in research facilities.

23. Government should make improvement in curriculum by comparing national curriculum with curriculum of different countries. 


\section{Macrothink \\ International Journal of Accounting and Financial Reporting \\ ISSN 2162-3082 2012, Vol. 2, No. 1}

24. Government should make improvement regarding quality of education.

25. Government should make such strategies so that adequate resources can be mobilized to increase the budget allocation in education sector of Pakistan.

26. Government should surmount the problems of corruption, inflation and rapid population growth that are directly influenced on lowering the literacy rate of Pakistan.

27. Government should endow with financial facilities to policy makers so that good policy making and policy implementation can be ensured.

\section{References:}

1. Addy, E.S. 2008. "Gender Equality in Juniors and Senior Secondary Education in Sub-Saharan Africa." The International Bank for Reconstruction and Development. The World Bank.

2. Ahmad, M. 2009. Oxfam Education Sector Policy Review. Oxfam GB Pakistan Programme.

3. Aikman, S. and Unterhalter, E. 2005. "Beyond access: Transforming Policy and Practice for Gender Equality in Education.” London: Oxford.

4. Ajuoga, M.A. 2000. "Impact of Instructional Materials on the Academic Performance of Selected Schools in Kisumu District in Kenya." An unpublished Masters Dissertation, Makerere University: Kampala.

5. Ali, M.A. 1997. "Incentives for Rural Female Students." Paper presented at National Conference on New Directions on Research for Women, held at Aga Khan University, Karachi, Pakistan.

6. Aly, J.H. 2007. "Education in Pakistan." A white paper revised. Document to debate and finalize the National Education Policy.

7. Aly, J.H. 2007. "Education in Pakistan: A White paper (Revised). Documentation to Debate and Finalize the National Education Policy. Islamabad: Government of Pakistan, National Education Policy Review Team.

8. Anderson, R. and Dexter, S. 2005. School technology leadership: An empirical investigation of prevalence and effect. Education Administration Quarterly, 1:49-82. Boston: Allyn and Bacon.

9. Andrabi, T. , J. Das, A.I. Khawaja, T. Vishwanath, T. Zajonic and the LEAPS Team. 2007. "Pakistan: Learning and Educational Achievements in Punjab Schools (LEAPS): Insights to Inform the Education Policy debate." Islamabad: World Bank. http//go.worldbank.org/YUFOT05SAO. Retrieved on 20-8-2009.

10. Aslam, M. 2009. "Education Gender Gaps in Pakistan: Is the Labor Market to Blame?" Economic Development and Cultural Change, Vol.57, pp.747-784. 


\section{Macrothink}

International Journal of Accounting and Financial Reporting ISSN 2162-3082

11. Aslam, M. 2009. "The Relative Effectiveness of Government and Private Schools in Pakistan: Are Girls Worse Off?” Education Economics, Vol.17, No.3, pp.329-354.

12. Bano, M. 2008. Public Private Partnerships (PPPs) as 'Anchor' of Educational Reforms: Lessons from Pakistan. Background Paper for Education for all Global Monitoring Report 2009. UNESCO, Islamabad.

13. Barnet, R. 1990. "The Idea of Higher Education.” Philadelphia, USA: The Society for Research into Higher Education.

14. Behraman, J.R. and J.C. Knowles. 1999. "Household Income and Child Schooling in Vietnam." World Bank Economic Review, Vol.13, No.2, pp.211-256.

15. Birdsall, N. , D. Ross and R. Sabot. 1995. "Inequality and Growth Reconsidered: Lessons from East Asia.” World Bank Economic Review, Vol.9, No.3, pp.477-508.3,

16. Boyle, S.A., J. Mace, M. Sibbons. 2002. "The Costs of Sending Children to School: A Six-Country Comparative Study, Synthesis Report, Education Research Papers 12830.” Department of International Development (DFID), UK.

17. Brown, P.H. 2006. "Parental Education and Investment in Children Human Capital in Rural China." Economic Development and Cultural Change, Vol.51, No.2, pp.131-157.

18. Bynner, J. and Parsons, S. 1997. "It doesn't get any better; the impact of poor basic skill attainment on the lives of 37 year olds. London: The Basic Skills Agency."

19. Chaudhry, A.R. , A. Iqbal, S.Y.M. Gillani. 2009. "The Nexus between Higher Education and Economic Growth: An Empirical Investigation for Pakistan." Journal of Commerce and Social Science, Vol.3, pp. 137-145.

20. Checchi, D. 2003. "Inequality in Incomes and Access to Education.” A Cross Country Analysis (1960-1995)." Labor, Vol.17, No.2, pp.153-201.

21. Deininger, K. 2003. "Does cost of Schooling Affect Enrollment by the Poor Universal Primary Education in Uganda." Economics of Education Review, Vol.22, No.3, pp.291-305.

22. Economic Survey of Pakistan. 2010. "Education." Government of Pakistan. Ministry of Finance. www.finance.gov.pk/

23. Falch, T. and J. Rattso. 1997. "Political Economic Determinants of School Spending in Federal States: Theory and Time Series Evidence." European Journal Of Political Economy, Vol.13, No.2, pp.299-314.

24. Fasih, T. 2008. "Linking Education Policy to Labor Market Outcomes." The International Bank for Reconstruction and Development/ The World Bank Washington DC.

25. Filmer, D. 2007. "If You Build It, Will They Come? School Availability and School 


\section{Macrothink}

International Journal of Accounting and Financial Reporting ISSN 2162-3082 2012, Vol. 2, No. 1

Enrollment in 21 Poor Countries." Journal of Developmental Studies, Vol.43, No.5, pp.901-928.

26. Filmer, D. and L.H. Pritchett. 2001. "Estimating Wealth Effects without Expenditure Data or Tears: An Application to Educational Enrollment in states of India." Demography, Vol.38, No.1, pp.115-132.

27. Glewe, P. and M. Kremer. 2005. "Schools, Teachers and Education Outcomes in Developing Countries." Second Draft of Handbook on the Economics of Education.

28. Glick, P. and Sahn, D.E. 2000. "Schooling of Girls and Boys in West African country: The Effects of Parental Education, Income and Household Structure." Economics of Education Review, Vol.19, No.1, pp.63-87.

29. Gropello, E.D. 2005. "Barriers to Better Quality Education in Central America." Based on Central America Education Strategy Paper by World Bank.

30. Hanusheck, E.A. and L.Woesmann. 2007. "The Role of Education Quality for Economic Growth.” Policy Research Paper No. 4122, World Bank, Washington, DC.

31. Hazarika, G. and A. Bedi. 2003. "Schooling Costs and Child Work in Rural Pakistan." Journal of Development Studies, Vol.39, No.5, pp.29-64.

32. Hooper, B. 1991. "Gender and Education in Epstein ed. Chinese Education: Problems, Policies and Prospects. Garland Publishing Inc., New York \& London.

33. Institute of Social and Policy Sciences. 2009. "A Presentation of effectiveness of Education spending: Post Budget scenario, Islamabad." International Studies in Sociology of Education, Vol. 12, No. 1, pp. 77-96.

34. Jam, S.C. 2005. "Education and Socio-Economic Development." Ashok Kumar Mittal Concept Publishing Company, New Delhi, India.

35. Kazmi, S.W. 2005. "Role of Education in Globalization: A Case of Pakistan." SAARC, Journal of Human Resource Development.

36. Kennedy, C.H. and Baxter, C. 2000. "Pakistan 2000." Lexington Books, Published in the United States of America by Lexington Books.

37. Klasen, S. 2002. "Low Schooling for Girls, Slower Growth for All? Cross Country evidence on the Effect of Gender Inequality in Education on Economic Development." The World Bank Economic Review, Vol.16, No.3, pp.245-373.

38. Kochar, A.2004. "Urban Influences on Rural Schooling in India." Journal of Development Economics, Vol.74, pp.113-136.

39. Leech. F.E. and Little, A. 1999. "Education, Culture and Economic Dilemmas for Development." Published in Great Britain New York.

40. Lloyd, C.B. , C. Mete and Z.A. Sathar. 2005. "The Effect of Gender Differences in Primary School Access, Type and Quality on the Decision to Enroll in Rural 
Pakistan.” Economic Development and Cultural Change, Vol.53, No.3, pp.685-710.

41. Mahmood, M. , T. Javaid, A. Baig. 1994. "Why Children Do Not Go to School in Pakistan-Some Estimates and Theoretical Framework." The Pakistan Development Review, Vol.33, No.4, pp.1231-1248.

42. Malik, Z.M. 2002. "Causes of Drop Out in Primary Schools of Sargodha Tehsil during the Years 1996-1997 and 1997-1998." Pakistan Journal of Applied Sciences, Vol.2, No.6, pp.646-648.

43. Mansori, G. 2006. "Migration, School Attainment and Child Labor: Evidence from Rural Pakistan.” Policy Research Paper Series 3946. The World Bank.

44. Memon,G.R. 2007. "Education in Pakistan: The Key Issues, Problems and New Challenges.” Journal of Management and Social Sciences, Vol.3, No.1, pp.47-55.

45. Nconco.F. 2006. "A comparative study of leadership and management approaches in further education and training colleges." A dissertation submitted in fulfillment for requirement for the degree of doctor of education. Nelson Mandela Metropolitan University.

46. Noorani, S. 2009. "Barriers to Girls Education, Strategies and Interventions." www.unicef.org.

47. Nsubuga, Y.K.K.2003, Development and examination of secondary in Uganda: Experience and challenges Kampala; Uganda.

48. Pakistan Poverty Reduction strategy Paper (PRSP). 2003. IMF Country ReportNo.4/24. International Monitoring Fund Washington, DC.

49. Pritchett, L. and D. Filmer. 1999. "What Education Production Functions Really Show: A Positive Theory of Education Expenditures." Economics of Education Review, Vol.18, No.2, pp. 223-239.

50. PRSP Annual Progress Report (Various years) published in working paper of Pakistan Institute of Economics (PIDE) in 2007.

51. Qayyum, A., I.Khawaja and A. Hayder. 2008. "Growth Diagnostics in Pakistan." Working paper of Pakistan Institute of Development Economics (PIDE), Islamabad.

52. Qureshi, S. 2004. "Pakistan: Education and Gender Policy for Girls Education: A Lifetime to Development." International Policy Fellowship 2003-2004, Center for Policy Studies. Retrieved on 13-3-2010.

53. Rahman, T. 2005. "Passport to Privilege: The English Medium Schools in Pakistan." Peace and Democracy in South Asia, Volume 1, Number 1, January 2005.

54. Rasian, Z. 2009. "Higher Education Governance in Developing Countries, Challenges and Recommendations: A Case Study of Iran." Non Partisan education Review, Vol.5, No.3. 
55. Robertson, K. 2009. "IRAQ: Higher Educations Uncertain Future.” University World News: The Global Window on Higher Education.

56. Sawada, Y. 1997. "Human Capital Investments in Pakistan: Implications of Micro-evidence from Rural Households." The Pakistan Development Review, Vol.36, No.4, pp.695-7112.

57. Shami, D.P.A. , I. Fazeelat, K.S. Hussain. 2005. "Development of Education in Pakistan." Academy of Educational Planning and Management, ministry of Education, Islamabad.

58. Shapiro, D. and B.O. Tambashe. 2001. "Gender, Poverty, Family Structure, and Investments in Children's Education In Kinshasa, Congo." Economics of Education Review, Vol. 20, No.4, pp.359-375.

59. Siddique, K. 2007. "Socio-Economic Determinants of School Progression in Pakistan." Applied Econometrics and International Development, Vol.7, No.2.

60. Suryadarma, D. , A. Suryahadi and S.Sumarto. 2006. "Causes of Low Secondary Enrollment in Indonesia." Paper presented at SMERU Research Institute.

61. Vachon, P. 2007. "Burkina Faso Country Case Study, Country Profile Prepared for Education for All Global Monitoring Report 2008-Education for All by 2015: Will we Make it? UNESCO, Paris.

62. Watkins, K. 2000. "The Oxfam Education Report." Oxfam GB in Association with Oxfam International, England.

63. World Bank. 2007. "Higher Education Policy Study." Volume 1: Strategic Directions for Higher Education in Turkey. Report No. 39679. Human Development Sector Unit Europe and Central Asia Region Document of World Bank.

64. World Development Indicators, 2007. The World Bank, 2007. 